\title{
Tax Planning of Personal Income Tax of College Teachers under New Personal Income Tax Law
}

\author{
Aihui Sheng \\ Yunyang Teachers' College, Shiyan, 442000, China
}

Keywords: Colleges; Personal income tax; Tax planning

\begin{abstract}
With the continuous improvement of China's economic level and the increase of national investment in education recently, the personal income of college teachers increases rapidly. Under this background, State Administration of Taxation proposes that the college teachers should be listed in the high income industry and be taken as the key object of personal income tax collection and management. In this paper, the principle and method of tax planning of personal income tax are introduced and then the tax planning of personal income tax scheme of college teachers under the new personal income tax law is discussed based on the analysis of the income composition of college teachers, hoping to reduce the tax burden of teachers by legal and reasonable tax planning means.
\end{abstract}

\section{Tax planning principle and method of personal income tax}

\section{Tax planning principle of personal income tax}

The tax planning means that the relevant operating activity of company or personal issues are pre-planned and arranged on the basis of not violating the provisions of current national tax laws so as to reduce the tax burden. The tax planning of personal income tax is one of the important contents of tax planning and is the process that the taxpayer reduces the tax burden by virtue of some methods and means for the purpose of maintaining its interests. In this process, the taxpayer should observe the following principles: first, law-abiding principle. The planning must be conducted within the allowable range of current national laws and regulations and the profit taking beyond the law for any reason is not allowed. Second, planning principle. The planning is the pre-arrangement and planning and the taxpayer is required to reduce the tax burden by planning and design before the generation of tax obligation in the process of tax planning of personal income tax. Third, benefit principle. The implementation of tax planning should fully consider whether the reduced tax burden is more than the expenditure of planning; if yes, the planning is meaningless.

\section{Tax planning method of personal income tax}

In China, the personal income tax, within the scope of classified collection, is divided into eleven types and different income has different collection standard. Therefore, the person income tax planning method is different. At the present stage, the research of tax planning method of personal income tax by most experts and scholars is mainly based on the tax basis and tax rate. Below is the common tax planning methods.

Tax preference

China's current tax laws specify that the allowance and subsidy not belonging to wage and compensation can be exempted from personal income tax, such as only-child subsidy, nursery fee subsidy, non-staple food subsidy and travel expense subsidy. In addition, the welfare expenses retained by enterprise and public institution, government agencies and social organizations and personal subsistence allowance paid by labor union expenditure can be exempted from personal income tax, so do the four social insurances and one housing fund within a certain limit. The certain limit is the proportional range specified by the state. The national preference policies can be fully used and it is allowed to seek for more interests for the taxpayer permitted by the laws and regulations. 
China implements the classified collection system in terms of personal income tax and there are different provisions for the collection of income of different nature. In the tax planning process, the nature of personal income can be changed according to the taxable items within the allowable scope of laws in order to reduce the tax burden.

Transfer of cost

The individual may have accommodation cost, travel expense and other fees in providing the service. If the unit can provide accommodation and transportation, it can reduce the labor income so as to reduce the tax burden.

Tax deferral

The performance of tax obligation can be delayed to get the time value brought by tax deferral, so as to reduce the tax burden.

\section{Divided income payment}

This method is that the lump-sum income can be paid by several times to reduce the taxable income tax so as to reduce the tax burden. The tax laws specify that the labor compensation of lump-sum payment is regarded as one time; for the continuous compensation of a same item, the income of a month is regarded as one time. The part-time income of college teachers belongs to the second circumstance, so it must increase the tax burden if it is paid by one time. But if the times of payment are adjusted, it can reduce the tax burden.

Income as welfare

If the personal cash wage can be changed into the welfare, it can also reduce the taxable personal income tax without changing the due wage. For example, the colleges can provide convenient transportation to the teachers because the travel expense is a necessary expenditure each month as many colleges are far from the downtown. Colleges can pick up the teachers freely by a regular bus or reimburse a certain amount of expense each month so as to reduce the tax burden without changing the total wage.

\section{Income composition of college teachers}

Compared with the general industry, college teachers have typical specificity, which is embodied in the wide and complicated income source. The personal income source of college teachers is generally as follows:

\section{Wage and salary}

The wage and salary are the basic income of college teachers, which can be divided into the following types:

1. Basic wage: basic remuneration of teachers according to their working age, title and relevant national provisions, which is stable and balanced.

2. Performance reward: mainly including the class hour allowance, that is, income of the daily teaching activity; thesis supervision allowance, that is, income of guiding the students to finish the thesis; experimental and practical guidance allowance, that is, income of guiding the experiment and practice of students, which is calculated according to the experimental and practice difficulty, nature and time. 。

3. Scientific research reward: income of scientific research activity of college teachers, mainly including the publishing of thesis with regard to the scientific research project and labor for subject research.

4. Year-end bonus: one-time annual bonus of teachers at the end of each year according to the relevant regulations of college.

\section{Remuneration for personal services}

It refers to the income of one-time labor of college teachers beyond class hour and scientific research, such as invigilation, review, consultation, overdue work, provision of relevant services for students and provision of labor for other units outside the school. 


\section{Remuneration for contributions}

It refers to the income of college teachers due to the publishing of their works on newspapers, magazines and other periodicals in the form of book and newspaper. The works mainly include character, picture, music score etc.

\section{tax planning scheme of personal income tax of college teachers under new persona income tax law}

\section{Tax planning of wage and salary}

The new personal income tax law implemented on September 1, 2011 species that the part of monthly personal wage and salary that is more than 3500 yuan should be taxed according to the level 7 excess progressive tax rate. In this case, colleges should take the part of income that is more than 3500 yuan as the teacher's welfare to reduce the tax burden and improve the welfare of teachers. Taking the class fee and year-end bonus as the example, the tax planning scheme of personal income tax of teachers is discussed.

Tax planning of class fee

The annual class fee of college teachers can be paid by lump sum at the end of year or paid by being distributed to each taxable period. According to the provisions of tax law, the class fee should be incorporated into the monthly wage and salary of teachers to pay the personal income tax. So teachers will pay more taxes if the class fee is paid by lump sum. To not increase the tax burden of teachers, colleges should distribute the class fee to each taxable period.

Example 1: Teacher Zhang's monthly wage is 4100 yuan and the class fee in the first half of the year is 9000 yuan.

Scheme 1: If the class fee is paid by lump sum, the taxable personal income tax in June is:

$(4100+9000-3500) \times 25 \%-1005=1395$ yuan

The taxable personal income tax from January to June is:

$(4100-3500) \times 3 \% \times 5+1395=1485$

Scheme II: The class fee is distributed to six months averagely, 1500 yuan per month, so the total taxable personal income tax from January to June is:

$[(4100+1500-3500) \times 10 \%-105] \times 6=630$

Comparing Scheme I with Scheme II, it is clear that Scheme II can save tax of 855 yuan.

Tax planning of year-end bonus

To introduce and retain talents, domestic colleges increase the year-end bonus to improve the treatment of teachers; however, the increase of year-end bonus may increase the personal income tax of teachers. If colleges fail to consider the total income of teachers and conduct tax planning of personal income tax of teachers when the year-end bonus is paid, it may lead to a situation that the taxable personal income tax is different with the same year-end bonus or the actual income decreases with the increase of year-end bonus, which may affect the work initiative of teachers. Therefore, the functional department of colleges should fully consider this problem and conduct tax planning of year-end bonus to reduce the personal income tax of teachers so as to improve the actual income and arouse the work enthusiasm of teachers.

Example 2: Teacher Zhang's monthly wage is 4500 yuan and the year-end bonus is 36000 yuan.

Scheme I: if the year-end bonus is paid by lump sum, the taxable amount of year-end bonus is:

$36000 \times 10 \%-105=3495$ yuan

The annual taxable amount is:

$(4500-3500) \times 3 \% \times 12+3495=3855$ yuan

Scheme II: if the bonus is paid in the middle of the year and at the end of the year respectively, 12000 yuan in the middle of the year and 24000 yuan at the end of the year, the taxable amount in the middle of the year and at the end of the year respectively is:

$(4500+12000-3500) \times 25 \%-1005=2245$ yuan

$24000 \times 10 \%-105=2295$ yuan 
The annual taxable amount is:

$(4500-3500) \times 3 \% \times 11+2245+2295=4870$ yuan

Comparing Scheme I with Scheme II, it is clear that Scheme I can save tax of 1015 yuan. Therefore, colleges should fully consider the influence of different distribution forms on the personal income tax of teachers when the year-end bonus is paid.

\section{Tax planning of remuneration for personal services}

According to the relevant provisions of personal income tax law, if the remuneration for personal services is the lump-sum income, the remuneration for personal services of lump-sum payment is regarded as one time; for the continuous compensation of a same item, the income of a month is regarded as one time. According to the provisions, to reduce the tax burden of the remuneration for personal services of college teachers, the remuneration for personal services can be paid by several times to distribute the service income in a certain period of time, or partial remuneration can be changed into the expense so as to reduce the total taxable amount. For example, the service receiver can use partial remuneration as the travel expense, board expense, accommodation fee and other expenses so as to reduce the tax burden by reasonably reduce the numeration for personal services.

The applicable tax rate of remuneration for personal services now is $20 \%$ and the specific tax payment means are: if the remuneration for personal services is less than 4000 yuan, the taxable personal income tax amount is the amount after deducing 800 yuan; if the remuneration for personal services is less than 4000 yuan, such remuneration is the taxable personal income tax amount; if the lump-sump remuneration for personal services is very high, additive tax will be collected, that is, if the taxable personal income tax amount is more than 20000 yuan but less than 50000 yuan, the tax rate is $30 \%$; if the taxable personal income tax amount is more than 50000 yuan, the tax rate is $40 \%$.

Example 3: Professor Zheng gives a lecture in an unit in other places and the personal service fee is 40000 yuan. In the personal service, the travel expense, board expense and accommodation fee of Professor Zheng are 15000 yuan.

Scheme I: If Professor Zheng bears the travel expense personally, the taxable amount is:

$40000 \times(1-20 \%) \times 30 \%-2000=7600$ yuan

The actual income is: $40000-7600-15000=17400$ yuan

Scheme II: If the unit bears the travel expense of Professor Zheng, the taxable amount is:

$(40000-15000) \times(1-20 \%) \times 20 \%=4000$ yuan

The actual income is: $40000-15000-4000=21000$ yuan

Comparing Scheme I with Scheme II, it is clear that Scheme I can save tax of 3600 yuan, which can be regarded as an effective method of tax planning.

\section{Tax planning of remuneration for contributions}

The tax calculation method of remuneration for contributions is: the personal income tax of the publishing of the same work of an individual in the form of book and newspaper, regardless of the payment mode of publishing unit, should be calculated by lump-sum payment of remuneration for contributions; if the same work is published and republished at two places or above, the personal income tax of remuneration for contributions is calculated by times. For college teachers, the tax planning method of remuneration for contributions is as follows:

Example 4: Professor Li publishes a work with regard to finance and the remuneration for contributions is 15000 yuan.

Scheme I: If the work is published by one book, taxable amount is:

$15000 \times(1-20 \%) \times 20 \% \times(1-30 \%)=1680$ yuan

Scheme II: If the work is published by four books, taxable amount is:

$(15000 \div 4-800) \times 20 \% \times(1-30 \%) \times 4=1652$ yuan

Comparing Scheme I with Scheme II, it is clear that Scheme I can save tax of 28 yuan. 


\section{Conclusion}

All in all, the income of college teachers has become the important collection object of personal income tax in China. Thus, colleges should positively explore the reasonable and legal tax planing means on the premise of paying tax by law and adopt corresponding tax planning scheme according to the income composition of teachers so as to reduce the tax burden, increase the disposable income and maintain the legal interests of teachers.

\section{Acknowledgments}

This paper is the school-level scientific research project achievement of Yunyang Teachers' College, project name: Tax Planning of Personal Income Tax of College Teachers, project number: 2014B01.

\section{References}

[1] Li Xue. Thinking on tax planning of personal income tax of College Teachers. Oriental Enterprise Culture, 2014(8).

[2] Huang Haibo. Research on tax planning of personal income tax of College Teachers. Science-Technology and Management, 2011(5).

[3] Yang Lihua. Research on tax planning of personal income tax of College Teachers. Assets and Finances in Administration and Institution, 2012(11).

[4] Zhang Yanqun. Problems in Tax Withholding and Planning of Personal Income Tax of College Teachers. Journal of Henan Institute of Science and Technology, 2012(5).

[5] Zhang Aixia, Yu Hongyan. Discussion on tax planning of personal income tax of College Teachers. Journal of Jiamusi Education Institute, 2011(2). 